\title{
Designing Transitional Programs to Meet the Needs of Multi-Ethnic First-Year Students
}

\author{
Daniel P. Nadler and Michael T. Miller
}

Colleges and universities often rely on transitional programs to convey a sense of institutional expectations to new students. These programs, however, are often defined and created from a perspective of history and tradition, and do not necessarily reflect the increasingly diverse college student population. Using the "CAS Standards for New Student Orientation," a student orientation program was reviewed with special attention to multi-ethnic student perceptions of the goals outlined in the standards. Using two years of data collection, the findings suggest that multi-ethnic students are more satisfied with the orientation program than are Caucasian students as measured by the CAS Standards.

Orientation and transitional programs have a variety of purposes, ranging from conveying institutional expectations to new students (Mullendore, 1992) to creating a feeling of cohesiveness among new entering students (Twale, 1989). Despite research and orientation purpose statements, the general consensus is that the role, mission, and function of an orientation program should largely be dependent on the environment and needs of an individual campus. Neither research nor application, however, often provide an examination of these intentions further than the institution, and typically neglect the notion of student differences within institutions.

Various students may have vastly different expectations of orientation programs, and research indicates that cultural and academic differences among entering freshman cohorts often exist. Nadler, Miller, and Casebere (1998) found that students who classified themselves as more academic or collegiate generally had more positive orientation experiences than those who classified themselves as vocational or nonconformist. These students typically agree more strongly with an orientation program's ability to address the issues outlined by the Council for the Advancement of Standards (CAS) in their Standards for New Student Orientation (1988). Additional research on transitional programming assessment differences has focused on areas such as transfer versus first-time enrollment status (Kramer \& Washburn, 1983; Gardner \& Hansen, 1993).

Research efforts to assess orientation and transitional effectiveness have not traditionally addressed issues of multi-ethnicity among participants. These multi-ethnic students, including African-American, Asian, Asian-American, and Hispanic students

Daniel P. Nadler, Ph.D., is Associate Dean of Students at Tulane University.nadler@mailhost.tcs.tulane.edu

Michael T. Miller, Ed.D., is Associate Professor and Chair of the Higher Education Administration and Leadership at the University of Alabama. mmiller@bamaed.ua.edu 
generally have been underrepresented in assessment measures for transitional programs. These students, comprising $21 \%$ of all college students today (Sax, Astin, Korn, \& Mahoney, 1995), are at times not operationally represented in orientation program development, and special attention to unique needs are seen as an "add-on" or separate module to the overall orientation program. There are instances when international students are provided a specific program, but these also tend to be additions to larger efforts. Many of these mainstream activities do not address the unique needs of multi-ethnic students. Stage and Manning (1992) argue that on many college campuses the model for participants in programs is either "assimilation into the dominant group's activities or separation and creation of new activities marginal to the mainstream of campus life" (p. 66).

This study was designed to explore the differences in orientation outcomes between multi-ethnic and majority first-year college students in order to examine the needs of minority students. Drawing on a three-year data set collected at a highly selective private research university, the CAS Standards were utilized as a rubric for orientation outcomes.

\section{Background of the Study}

Orientation and transitional programs are designed to fulfill a number of purposes. These purposes range from campus safety and security issues to tips on achieving academic success. Institutions commonly utilize a cumulative growth paradigm toward creating and evaluating orientation programs, one in which attendance is the primary indicator of success. The cumulative growth perspective on assessing programs is similar to what Wildavsky (1987) referred to as irrational budgeting, where the previous year's effort (or budget) is modified and separated, and substantially changed only when there is a change in policy or a major problem.

This approach to orientation programming is deficient in at least one major area: Those who may be neglected will continue to be neglected until they amass either enough vocal power or enough problems to warrant a significant change. Kerr (1991) referred to this type of constituent reaction as a responsive critical mass.

Minority students frequently have unique needs that must be addressed through transitional or orientation programs. On some campuses these students constitute such a small number that specialized programming is neither practical nor cost effective. Their needs, however, are nonetheless important and a powerful introductory experience, such as orientation, can convey the institutional message of concern for their wellbeing. In addition, institutional expectations concerning collaboration, peer support, racial diversity, and cohesiveness can be discussed.

Research and reported trends indicate that multi-ethnic students often have differing expectations of the collegiate experience (Pascarella \& Terenzini, 1991) and, subsequently, of the transitional experience into college. 


\section{Research Methods}

A case study research design was used to collect data for the study. As part of a larger investigation into the overall assessment of an orientation program, a variable based on ethnic self-identification was used to stratify an existing data set. The data set was collected from 1997 and 1998 orientation cohorts of first-year and transfer students at a highly selective private institution of approximately 5,000 undergraduate students.

The institution engaged in a self-study of orientation effectiveness and utilized the CAS Standards for New Student Orientation as a guiding framework for the rationale of the orientation program. The cohort group of 1998 was 835 students and the 1997 year included 1,043 students. The surveys were distributed to all orientation program participants during the last day of a four-day pre-semester orientation program. Due to the voluntary nature of the data collection, the cohort response sizes were between $80 \%$ and $90 \%$ of all students completing the orientation program.

Included on the survey was an item requesting the respondents to indicate the ethnic descriptor that they perceive to best describe themselves. The options were African-American, American Indian, Asian, Hispanic, Caucasian, and Other. The CAS Standards were listed with a statement requesting respondents to identify their views on how well the orientation program achieved each item. Respondents used a 1-to-5 Likert-type rating scale, as created and pilot tested by Nadler and Miller (1997).

An internal reliability correlation analysis on the items comprising the CAS Standards for New Student Orientation yielded an alpha level of .91 and a standardized alpha of .92, indicating a strong level of internal reliability.

\section{Findings}

Of the total 1,867 students completing surveys during the two cohort years, 1,561 classified themselves as Caucasian and 306 identified themselves as one of the other multi-ethnic groups (see Table 1). The largest groups of minority students were Asian ( $40 \%$ of minority students) followed by Hispanics (23\% of minority students). The disparity of cell sizes represents the dominant culture of the institution, and prevents a statistical analysis of differences among ratings.

TABLE 1

Multi-Ethnic Survey Participants, 1997 and 1998

\begin{tabular}{lll} 
Ethnic Self-Identification & Freq & \% of Total \\
\hline African-American & 58 & 19 \\
American Indian & 11 & 3 \\
Asian & 123 & 40 \\
Hispanic & 71 & 23 \\
Other & 45 & 15 \\
Total & $\mathbf{3 0 8}$ & $\mathbf{1 0 0 \%}$ \\
\hline
\end{tabular}


Overall, the CAS Standards had a mean rating of 3.79, indicating a perception between "uncertain of the standards fulfillment" to "agreeing that the standard was achieved." The students who identified themselves as Caucasian had an overall mean rating of 3.79 on the 20 CAS Standards, with a range in individual ratings of 4.19 (positive relationships with other new students) to 3.48 (positive relationships with faculty). Multi-ethnic students reported a moderately higher overall mean rating of 3.81, with a less broad range of 3.59 (purpose in attending the university) to 4.15 (developing positive relationships with other new students).

Multi-ethnic students rated 11 of the 20 standards higher than their nonmulti-ethnic counterparts, eight standards lower, and one standard the same. Due to the exaggerated difference in cell sizes, no statistical test of significant differences was attempted. However, as shown in Table 2 some had a difference of .20 or more, and were thus noteworthy. For instance, the multi-ethnic student cohort agreed more strongly than their nonmulti-ethnic counterparts on two of the CAS standards: developing positive relationships with faculty and discussing expectations with continuing students. Only one standard was rated 20 or more strongly by the nonmulti-ethnic students: providing information and an atmosphere to make reasoned and well-informed decisions. The majority of all differences, in either direction, were under .10 on the 1-to-5 Likerttype rating scale.

\section{TABLE 2}

\section{Student Agreement with the CAS Standards by Multi-Ethnic and Non Multi-Ethnic Student Mean Ratings}

\section{Orientation Goal}

$$
\begin{aligned}
& \mathrm{M}-\mathrm{E} \\
& \mathrm{n}=306
\end{aligned}
$$

Non-M-E

Overall

$\mathrm{n}=1,561$

$\mathrm{N}=1,867$

\section{Assisted me in...}

understanding the purposes

of the university.

understanding the mission

of the university. 
developing positive

3.76

3.65

3.67

relationships with

university staff.

developing positive

4.15

4.19

4.19

relationships with

other new students.

developing positive

relationships with individuals

from my community.

understanding the

university's expectations of me.

Student Agreement with the CAS Standards by Multi-Ethnic and Non Multi-Ethnic Student Mean Ratings

Orientation Goal

M-E

$\mathrm{n}=306$

Assisted me in...

identifying the costs

3.60

3.53

Non-M-E

Overall

of attending the university,

both in terms of dollars and

personal commitment.

developing familiarity

3.92

3.97

3.96

with the physical surroundings.

\section{And they...}

Provided information 3.58

about opportunities for self-assessment.

Provided an atmosphere and

sufficient information that enabled me to make reasoned and well-informed decisions. 
Provided information

4.09

4.08

4.08

concerning academic policies,

procedures, requirements, and programs.

Promoted an awareness of

4.05

4.06

4.06

nonclassroom opportunities.

Provided referrals to

qualified advisers and counselors.

Explained the process for

3.84

3.80

3.81

class scheduling and registration.

Student Agreement with the CAS Standards by Multi-Ethnic and Non Multi-Ethnic Student Mean Ratings

$\begin{array}{llll}\text { Orientation Goal } & \text { M-E } & \text { Non-M-E } & \text { Overall } \\ & n=306 & n=1,561 & N=1,867\end{array}$

The orientation program...

Provided information and

exposure to available

institutional services.

Created an atmosphere that

minimized anxiety, promoted

positive attitudes, and stimulated

an excitement for learning.

Provided appropriate

4.08

4.08

4.08

information on personal safety

and security.

Provided opportunities to

discuss expectations and perceptions with continuing students. 


\section{Discussion}

The expectations of multi-ethnic students need to be considered when planning outcomes for transitional programs. International students, in specific, may have unique needs for which a cross-cultural approach to orientation program design may be appropriate and effective. In order to address these issues in a meaningful fashion, however, the initial question of orientation purpose, or mission, must be identified. Too often, orientation programs are built around a general consensus of expectations, but fail to specifically identify a mission or purpose. If orientation professionals hope to realistically address orientation or transitional programs in response to diverse student needs, there must be some effort to initially identify the parameters defining what orientation "should be" before additional sessions and objectives are added.

Assuming that a mission statement or objective is developed for an orientation experience; e.g., the adoption of the CAS Standards, particular attention must be given to diverse student needs and the manner in which these needs is addressed. Of particular interest in this study was the fact that multi-ethnic students had a moderately stronger agreement with the opportunities to discuss expectations and perceptions with continuing students than their counterparts. This may be, in part, a way in which to minimize or at least reduce cultural dissonance (Stage and Manning, 1992). Since students learn from other students, orientation professionals may find it meaningful to build in time to meet with role model multi-ethnic students. Many international students, for example, may find it particularly helpful to see someone from their home countries with whom they can talk about host institution expectations.

Reinforcing this idea that students may need an opportunity to find others like themselves is the fact that nonmulti-ethnic students agree more strongly that orientation provides an atmosphere conducive to making reasoned and well-informed decisions. The findings indicate that the culture of the orientation experience needs to be supportive of diversity. This culture must also be rich in understanding differences, while simultaneously conveying the expectations of the institution to new students.

The orientation experience is complex, and the responsibility invested in orientation professionals is vital to student success. Every effort must be made by these professionals to recognize student differences, and, at the very least, respect the cognitive and social implications of these differences.

\section{References}

Gardner, J. N., \& Hansen, D. A. (1993). Perspectives on the future of orientation. In M. L. Upcraft (Ed.). Designing Successful Transitions: A Guide for Orienting Students to College, pp. 183-194. Columbia, SC: Freshman Year Experience.

Kramer, G., \& Washburn, R. (1983). The perceived orientation needs of new students. Journal of College Student Personnel, 24, 311-319.

Kerr, C. (1991). The great transformation in American higher education. Albany, NY: State University of New York. 
Mullendore, R. H. (1992). Student based programming in orientation. In D. P. Nadler (Ed.). Orientation Director's Manual (pp. 43-52). Statesboro, GA: National Orientation Director's Association.

Nadler, D. P., \& Miller, M. T. (1997). Student satisfaction with orientation: A program assessment and cultural stratification. Journal of College Orientation and Transition, 5(1), 7-14.

Nadler, D. P., Miller, M. T., \& Casebere, J. (1998). Student satisfaction with orientation: Toward a framework for program effectiveness. The Journal of College Orientation and Transition, 6(1), 27-35.

Pascarella, E. T., \& Terenzini, P. T. (1991). How college affects students. San Francisco: Jossey-Bass.

Sax, L. J., Astin, A. W., Korn, W. S., \& Mahoney, K. M. (1995). The American freshman: National norms for fall 1995. Los Angeles, CA: ACE/UCLA, Cooperative Institutional Research Program.

Stage, F. K., \& Manning, K. (1992). The cultural broken and the cocurriculum. In Enhancing the Multicultural Campus Environment: A Cultural Brokering Approach. New Directions for Student Services, No. 60. San Francisco: Jossey-Bass.

Twale, D. J. (1989). Social and academic development in freshman orientation: A time frame. NASPA Journal, 27, 160-167.

Wildavsky, A. (1987). The new politics of budgetary process. Glenview, IL: Scott, Foresman, and Company. 